\title{
河口潮間帯干潟の土砂動態に及ぼす潮汐と河川出水の相対的重要度
}

\section{Relative Importance of Tide and River Discharge on Sediment Transport on Intertidal Flat}

\author{
山田文彦 ${ }^{1} \cdot$ 白川雄一朗 ${ }^{2} \cdot$ 舟越善隆 $^{3} \cdot$ 田川一彦 ${ }^{4} \cdot$ 外村隆臣 $^{5}$ \\ 坂西由弘 ${ }^{6}$. 小林信久 ${ }^{7} \cdot$ 玉置昭夫 $^{8}$. 多田彰秀 ${ }^{9}$ \\ Fumihiko YAMADA, Yuichiro SHIRAKAWA, Yoshitaka FUNAKOSHI \\ Kazuhiko TAGAWA, Takaomi HOKAMURA, Yoshihiro SAKANISHI \\ Nobuhisa KOBAYASHI, Akio TAMAKI and Akihide TADA
}

\begin{abstract}
Relative importance of tidal motions and river discharges for the sediment transport was evaluated using field measurements and data analysis on an intertidal flat adjacent to the Shirakawa River mouth. Monthly-averaged sediment budgets during flood periods indicated the different pattern at the closest point to the river mouth. Sediment is transported to north during non-flood period while transported to south during flood period at this point. The basinscale tidal motions are found to be important for the sediment transport during non-flood period. The phase relationships between the peak river discharge and tide level during the flood are most important for the sediment transport on the intertidal flat adjacent to the river mouth in the fetch-limited closed bay.
\end{abstract}

\section{1.はじめに}

地球温暖化の影響により，沿岸域においては海面上昇 や高潮・高波による災害リスクの増大等も䀣念されてい る. 特に，内湾に位置する干潟は種々の外力変動の影響 を受けて容易に変形・消失すると考えられており，潮間 帯干潟上での土砂動態のメカニズムを把握することは沿 岸防災計画上においても極めて重要な研究課題のひとつ と位置づけられる。

栗山・橋本 (2004), Harris ら（2005）, 山田ら（2007） などの研究により，短期地形変動に及ぼす高波浪の影響 や平均場に及ぼす潮汐の影響，また，中・長期的地形変 動に対する河川出水の重要性などが指摘されている。し かし，これまで継続的な連続観測に基づいて，河口潮間 帯干潟の土砂収支に及ぼす潮汐・河川出水の相対的な重 要度の検討を行った例は少ない. 山田ら（2009）は, ト ータルステーションを用いた直接地盤高測量と潮間帯干 潟上での底質の浮遊輸送フラックス計測を併用し，シル 卜・粘土の質量に基づいた土砂収支法を提案し, 熊本県 白川河口域の潮間帯干潟上での土砂収支に適用すること

\begin{tabular}{|c|c|c|}
\hline 1 正会員 & 博 (工) & 熊本大学教授 大学院自然科学研究科 \\
\hline 2 正会員 & 修(工) & 日本工営 本社 \\
\hline 3 学生会員 & & 熊本大学大学院 自然科学研究科 \\
\hline 4 学生会員 & & 熊本大学大学院 自然科学研究科 \\
\hline 5 正会員 & & 熊本大学工学部 技術部 \\
\hline 6 正会員 & 修(工) & 鹿島建設（株） \\
\hline 7 & Ph. D & $\begin{array}{l}\text { デラウェア大学教授 応用海岸研究セン } \\
\text { ター }\end{array}$ \\
\hline 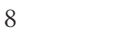 & 理十 & 長崎大学教授 \\
\hline 9 正会員 & 工博 & 長崎大学教授工学部 \\
\hline
\end{tabular}

で, 河川出水量と土砂動態の関係などについて検討し ている。しかし, 出水時の土砂動態に及ぼす河川出水 のピークと潮位の位相差の影響などについては未解明 である。

そこで本研究では地盤高と底質浮遊フラックスを連続 的に調べるとともに, 出水時の土砂動態に及ぼす河川出 水のピークと潮位の位相差の影響などについて検討した。

\section{2. 現地観測}

観測は図-1に示す熊本県白川河口域の潮間帯干潟上で 実施した。対象領域には6本の観測ラインを設置してお り, 左岸 Lラインと右岸 R3 ラインは 2000 年 12 月から, 右岸 R3 以外の 4 ラインは2004年 5 月から毎月干潟地盤高 の現地観測を実施し，現在も継続中である。また，底質 の浮遊輸送フラックス計測のため, 水位・流速・濁度 · 塩分の計測機器を R2 ライン上の堤防から沖に約 $400 \mathrm{~m}$ の $\mathrm{A}$ 点, 約 $1,040 \mathrm{~m}$ の B 点および約 $1,520 \mathrm{~m}$ の C 点の 3 ヶ所に 設置した。地盤高測量および底質の浮遊輸送フラックス 計測手法の詳細はYamadaら（2009）に詳しい。次節に 示す山田ら（2009）の土砂収支の検討結果より，河川出 水の影響は河口付近の境界線上に顕著に現れたため, R1

表-1 底質浮遊輸送フラックスの計測概要

\begin{tabular}{c|c|c|c}
\hline 観測点 & 観測期間 & 観測潮汐数 & 平均水没時間 \\
\hline A & 2005年10月 2006年 8 月 & 141 & $6.3 \mathrm{~h}$ \\
\hline B & 2004年 7月 2009年12月 & 2,142 & $8.1 \mathrm{~h}$ \\
\hline $\mathrm{C}$ & 2006年10月 2007年10月 & 280 & $9.2 \mathrm{~h}$ \\
\hline $\mathrm{D}$ & 2008年 5 月 2009年11月 & 851 & $7.6 \mathrm{~h}$ \\
\hline
\end{tabular}






図-1 現地観測場所（白川河口域）

ライン上の堤防から沖に約 $1,000 \mathrm{~m}$ に観測点（D点）を追 加し, 同様の底質浮遊輸送フラックス計測を実施した。 4地点の観測概要を表-1に示す.

山田ら（2009）は，2006年 10月～2007年 10月の期間 で直接地盤高測量と $\mathrm{A}, \mathrm{B}, \mathrm{C}$ 点での底質浮遊フラックス 計測結果を併用し，シルト・粘土の質量に基づく土砂収 支を検討した。具体的には，図-2の $\mathrm{R} 5$ 境界と R2 境界に 挟まれた領域を北側，また R2 境界と R1 境界に挟まれた 領域を南側とし，次式で算定した。

北側 : $Q_{A 1}=Q_{S}+Q_{W 1}+Q_{N}$

南側 : $Q_{A 2}=Q_{S}+Q_{W 2}+a \cdot Q_{R}$

ここで, $Q_{A 1} \cdot Q_{A 2}$ は地盤高測量から求めた地盤高変化に 寄与するシルト量, $Q_{N}$ は北側境界から流入・流出するシ ルト量, $Q_{S} \cdot Q_{W 1} \cdot Q_{W 2}$ は浮遊フラックス計測から求め た沿岸・岸沖方向の流入・流出シル卜量, $Q_{R}$ は河川から 流入するシルト量, $a$ は干潟地形変化への寄与率である.

解析の結果, 平常時・出水時に関わらずR5 - R2 境界 からは常に南向きの土砂移動が存在しており, また, 河 口に近いR1境界でも出水時に河口側へ土砂は流出し, 干 潟は侵食傾向を示す結果が得られた。 上記の理由につい て, 以下の $2 つ の$ 仮説を立て, 今回検討を行った.

(1) R5・R2 境界での南向きの土砂移動は, 潮流の空間 分布や湾全体の潮汐運動の影響に起因する.

(2) 河口に近い 1 境界での土砂移動は, 河川出水のピー

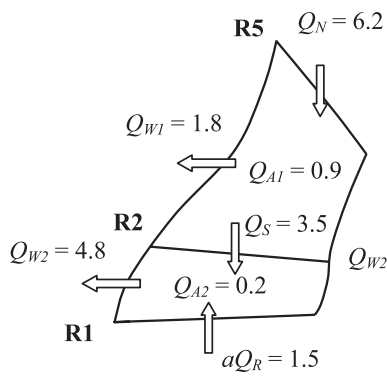

(a) 平常時
$Q_{N}=13.6$

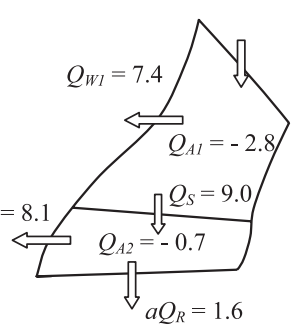

(b) 出水時
図-2 土砂収支結果 (単位：1.0 × $10^{6} \mathrm{~kg} /$ 月; 山田ら, 2009)
クだけでなく，潮位との位相関係に影響を受ける.

\section{3. 潮汐運動の空間分布が海水・底質輸送に及ぼ す影響}

\section{1）潮汐位相平均による海水・底質輸送フラックス特性}

水没と干出を繰り返す潮間带上で計測された不連続か つ不等間隔の時系列データから, 平均潮位差による成分, 大潮・小潮などの潮位差によって変動する成分, および 波動による成分を分離するため，山田ら（2007）は，一 潮汐毎に時系列デー夕を重称合わせた潮汐位相平均手法 を提案した。具体的には，上げ潮時に 20 秒間平均水位が 海底面から $30 \mathrm{~cm}$ (濁度計の設置位置に相当）を超える時 間を一潮汐の開始時間 $t_{1}$, また下げ潮時にそれを下回る 時間を一潮汐の終了時間 $t_{2}$ とし, その間 $\left(t_{2}-t_{1}\right)$ を一潮 汐間の水没継続時間 $T$ と定義する. 水没時間内に扔ける 20 秒間平均値を抽出し, 3 次スプライン関数を用いて時 間方向に内挿することで，時系列を作成する．このとき， 1 潮汐毎の水没継続時間の変動による影響を取り除くた めに，(3）式のような無次元水没時間 $t *$ を定義し, 一潮 汐毎に時系列を無次元の時間軸上 $\left(0 \leq t_{*} \leq 1\right)$ に重ね 合わせる. 無次元水没時間 0.5 が満潮に相当する.

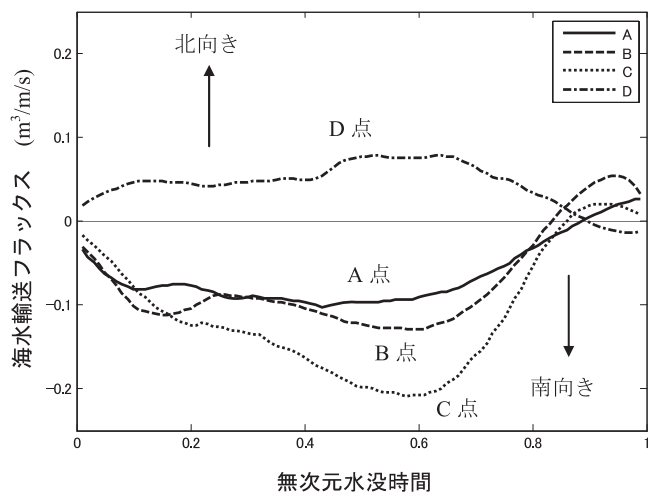

a）海水輸送フラックスの時間変化（沿岸方向）

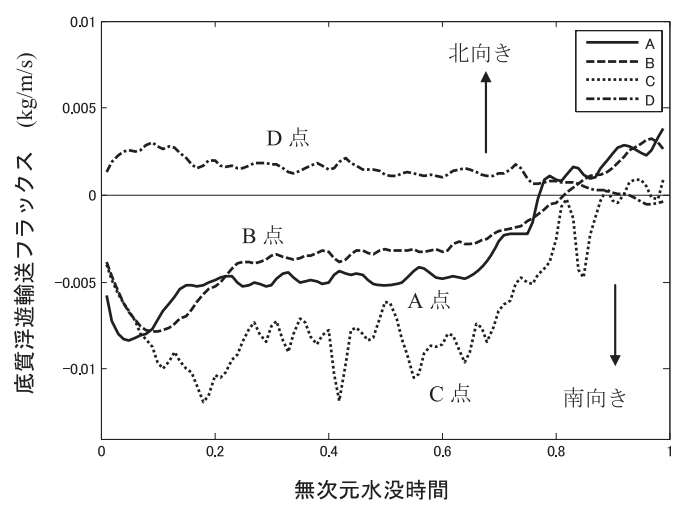

b) 底質浮遊輸送フラックスの時間変化（沿岸方向）

図-3 潮汐位相平均による平均的な海水 - 底質輸送特性 


$$
t_{*}=\frac{t-t_{1}}{T}, \quad t_{1} \leq t \leq t_{2}, \quad 0 \leq t_{*} \leq 1
$$

図-3 は, 潮汐位相平均による A, B, C, D 地点の沿岸 方向の海水・底質浮遊輸送フラックスの時間変化を示し ており, まず各点の平均的な海水および底質浮遊輸送フ ラックスの輸送方向について比較する．R2 ライン上の3 点（A， B, C 点）は，ともに南向きの輸送が卓越するが, 河口により近い R1 ライン上のD点はそれらとは逆位相と なり, 北向きの輸送が卓越する。これら海水・底質浮遊 輸送フラックスの卓越方向は, 前節の平常時 (平均的) の土砂収支結果とよく一致する. 次に, 各点の海水・底 質浮遊輸送フラックスの大きさに着目すると, R2 2 イン 上の 3 点 $(\mathrm{A}, \mathrm{B}, \mathrm{C}$ 点）に比べて $\mathrm{D}$ 点では, 海水輸送フ ラックスで $1 / 2$, 底質浮遊輸送フラックスで $1 / 4$ 程度の大 きさである。また，D点での水没時間中の変動は他の3 点に比較して小さく, 特に, 底質浮遊輸送フラックスに は潮汐の影響が明確には見られない。

図-4は，岸沖方向の時間変化も含めた海水・底質浮遊 輸送フラックスの時空間分布を比較するために，ベクト ル表示したものである，A，B，C点は，上げ潮・下げ潮 時は地形の等深線にほほ直交する方向に海水・底質輸送 が生じ，上げ潮時は岸向き，下げ潮時は沖向きである. また，満潮時にも等深線に沿って南向き（白川側）へ向 かう輸送が存在し，1潮汐間では，海水・底質とも南向 きの輸送が卓越する。一方 D点は, 上げ潮は沖向き, 満 潮時は北向き，下げ潮時は岸向きであり，1潮汐間では 海水・底質とも北向きの輸送が卓越する。このような非 対称性の強い平均流の発生要因として, Le Hirら（2000） は，沿岸域での広域循環の影響を指摘しているが，河口

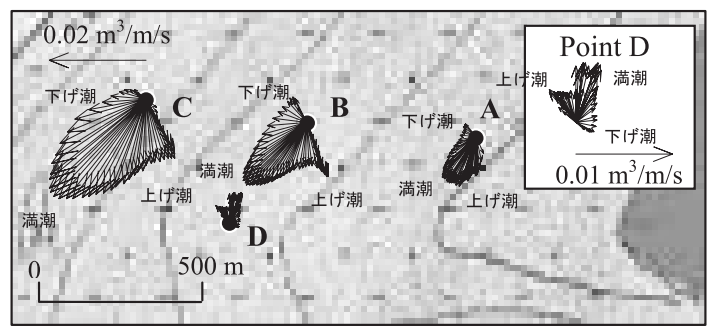

a）海水輸送フラックス

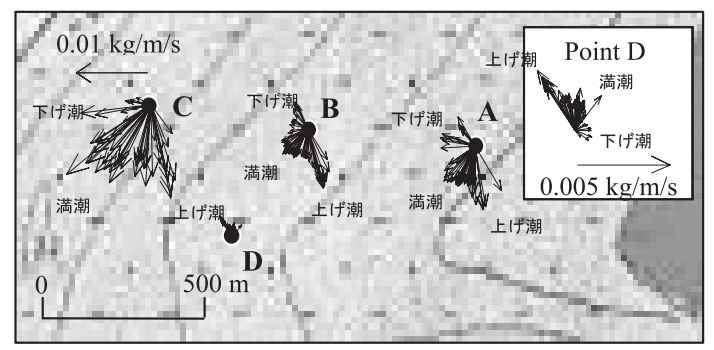

b）底質浮遊輸送フラックス

図-4 潮汐位相平均による海水・底質輸送特性 (ベクトル表示)
域に適用した場合，広域循環と河川流入との相互作用に ついても検討することが重要と考えられる.

\section{2) 理論的検討}

$\mathrm{R} 2$ ライン上の $\mathrm{A}, \mathrm{B}, \mathrm{C}$ 点の海水・底質輸送フラック スの卓越方向がすべて南向きとなる理由については，湾 全体の潮汐運動や水面および地形勾配の影響などが考え られるので，本節では理論的な考察を行う. Friedrichs • Aubrey（1996）は，連続の式のみを用いた岸沖1次元の 潮汐流の理論解を示した。この考え方は，浅水方程式の 各項 (局所加速度項, 移流項, 水面勾配項, 底面摩擦項) の中で，水面勾配項のみを卓越項として取り扱うことに 相当するため, 水面の空間分布が考慮されない. そこで, 連続の式のみを用いながら, 水面の空間分布も考慮し, 潮流の空間変化を理論的に考察可能なモデルを構築す る。そのため，基礎方程式である平面 2 次元の浅水方程 式を現地スケールで無次元化し，オーダリングを行った. その結果, 対象海域では, 水面勾配項のみでなく, 底面 摩擦項も考慮し，連続の式のみで平面的な流速成分を決 定する方法を提案した。具体的には，地盤高と等深線に 垂直・平行な潮流の断面平均成分を導入し，連続の式を (4) 式のように変形する.

$$
\begin{aligned}
& \frac{\partial \eta}{\partial t}-\frac{f_{b}\left(U_{n}^{2}+U_{p}^{2}\right)^{1.5}}{2 g H}=\left(U \frac{\partial z_{b}}{\partial x}+V \frac{\partial z_{b}}{\partial y}\right)-H\left(\frac{\partial U}{\partial x}+\frac{\partial V}{\partial y}\right) \\
& \begin{array}{c}
U_{n}=U \cdot n_{x}+V \cdot n_{y}, U_{p}=-U \cdot n_{y}+V \cdot n_{x} \\
\vec{n}=\left(n_{x}, n_{y}\right)
\end{array}
\end{aligned}
$$

ここで， $x, y$ は空間座標， $t$ は時間， $\eta$ は潮位， $f_{b}$ は底面 摩擦係数, $g$ は重力加速度, $U, V$ は東西 ·南北方向の潮 汐の断面平均流速， $U_{n}, U_{p}$ は等深線に垂直・平行な潮流 の断面平均成分, $\vec{n}$ は等深線の法線ベクトル, $z_{b}$ は地盤高, $H$ は全水深である。つまり，(4) 式の左辺第1項は潮位 の時間変化, 左辺第 2 項は底面摩擦, 右辺第 1 項は潮流 と地形勾配（測量結果より既知）の積，右辺第 2 項は潮 流の空間変化（水深積分のため通常ゼロではない）を意 味する. 次に，(4) 式の各項に潮汐位相平均值をそれぞ れ代入し，各項のオーダーを時系列で比較することで， 右辺第2 項の影響を調べた。

図-5より，B，C点ともに各項の大きさと時間変化は同 様の傾向を示しており, 左辺第2項（底面摩擦項）は他 項に比べると無視できるものの，右辺第2 項（潮流の空 間変化）は無視できない大きさであることがわかる．つ まり，潮間帯上での潮流の空間分布は有意な大きさを持 つことが確認された。そこで，潮下带を含めた湾全体の 潮汐流の空間分布の影響を検証するために，国土交通省 九州地方整備局港湾空港部が公開している有明海におけ 


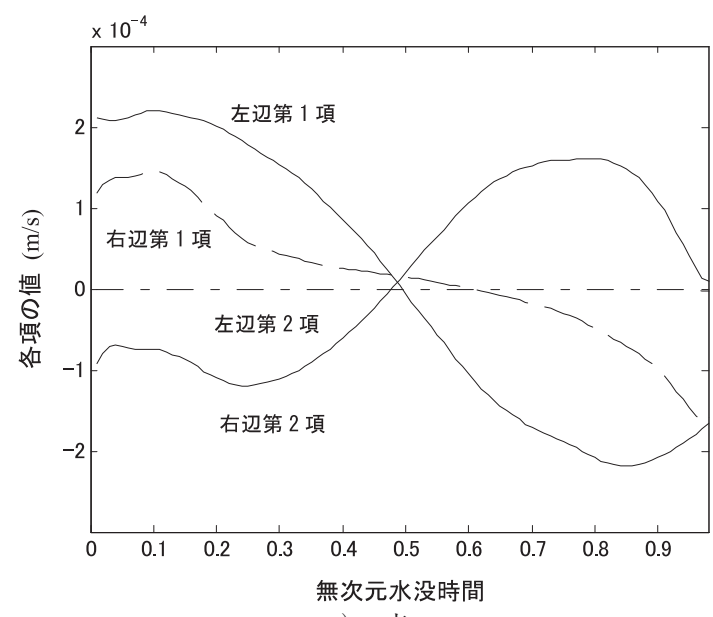

a) B点

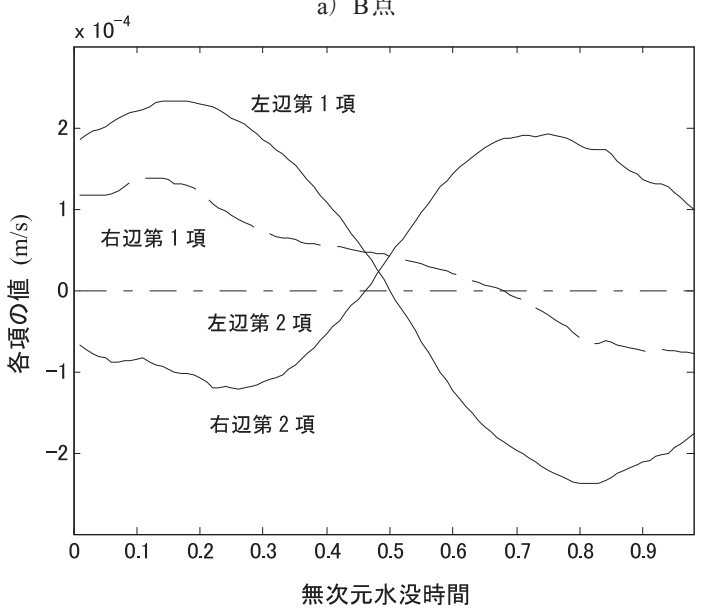

b) $\mathrm{C}$ 点

図-5（4）式中の各項の時間変化

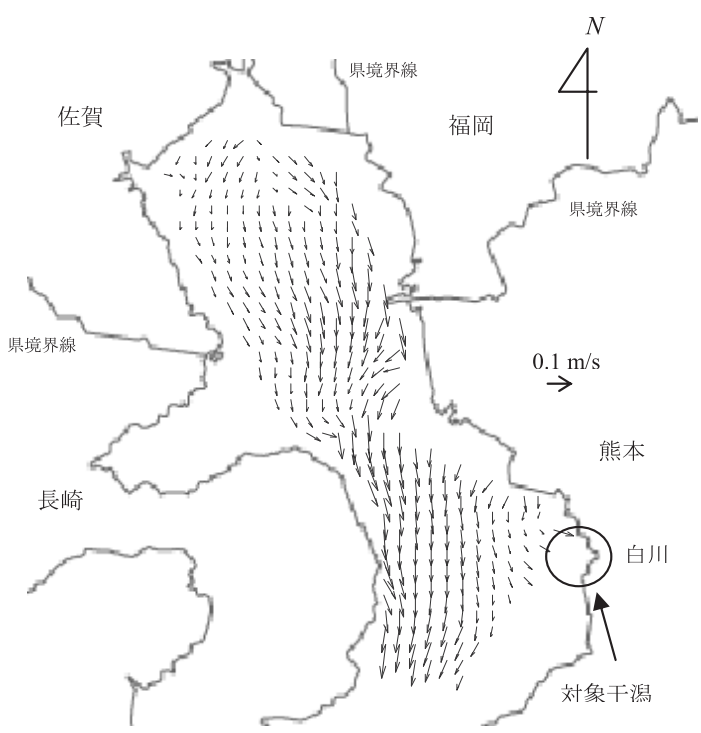

図-6 HFレーダによる表層付近の平均流速の空間分布 (有明海：2009年2月-5月）
るHFレーダの観測結果を用いて検討した.

図-6は，HFレーダによる観測結果を基に 2009 年 $2-5$ 月の平均表面流速・流向分布を求めた結果である。図よ り，湾全体においても表面付近の平面流速は南向きの流 れが卓越していることが確認できる．HFレーダによる観 測範囲には本潮間帯は含まれないが，同期間に対象潮間 帯で実施した11台のフロートブイの漂流実験において も，南下する流れが確認された（西ら，2010）。これら の結果より，1つ目の仮説である湾スケールの潮汐運動 が潮間帯上の流れや底質輸送にも影響を与えている事が 確認できた.

\section{4. 潮汐と河川出水の相対的な重要度の検討}

2つ目の仮説である土砂収支に対する河川出水のピー クと潮位の関係を検証するために，河口付近で特異な変 化を示しているR1 ライン上D点において観測を行い, 2008 年 5 月から 2009 年 11 月の間で底質浮遊フラックス量 と河川流量との比較を行った（図-7). 図より，2008年 の出水時には底質浮遊輸送フラックスの卓越方向は南向 きであるが，2009年の出水時には北向きの輸送量が卓 越している。この異なった輸送方向の生じた原因につい てさらに検討するために，2008年6月10-15日と2009年 7 月23-28日の出水時において図-8に示すように河川流 量と潮位の時系列を直接比較することで定量的な検討を 行った。
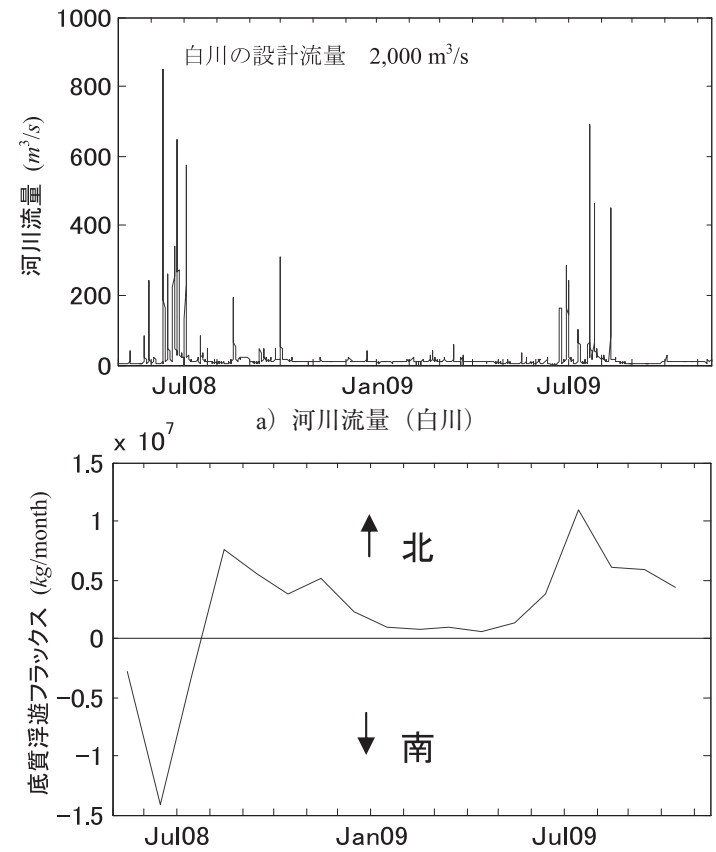

b） D点の沿岸方向の底質浮遊輸送フラックスの時系列

図-7 河川流量と D点の底質浮遊輸送フラックスの関係 2008 年 5 月～2009年 11 月 


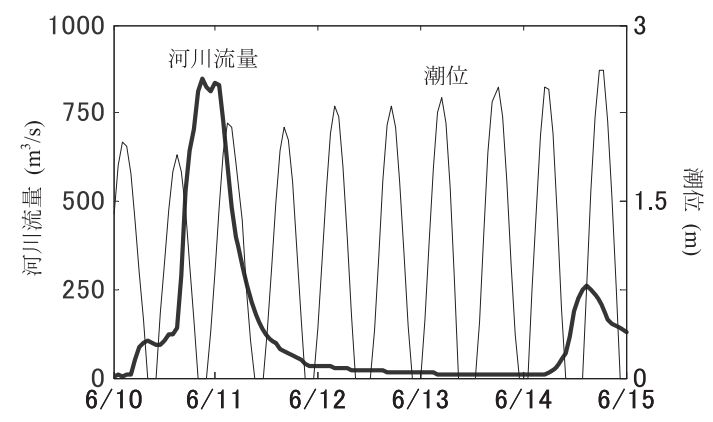

a) 2008 年 6 月 10 日〜 2008 年 6 月 15 日

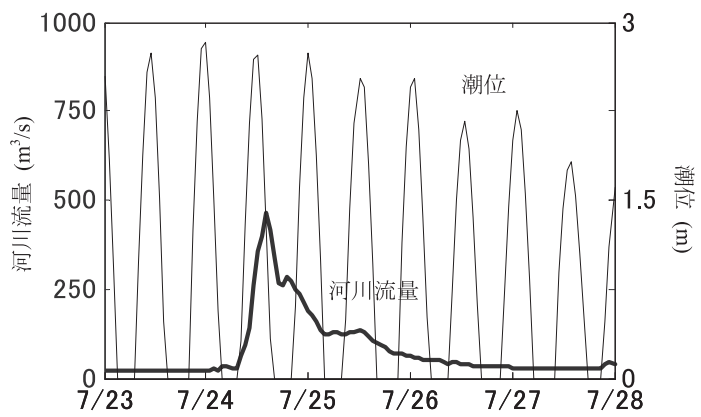

b） 2009 年 7 月 23 日 2009 年 7 月 28 日

図-8 河川出水と潮位の位相関係

図-8より，2008年6月 11 日の出水は下げ潮時から生じ, 干潮時に出水のピークを迎えている。そのため，潮間帯 上の底質は下げ潮による沖向き流れが過剰な河川出水に より南側に引き达まれるように南向きに輸送されたもの と考えられる。一方，2009年7月24日の出水時において は, 上げ潮から満潮にかけて出水のピークを迎えており, 潮位と出水の位相（タイミング）が2008年6月 11 日の出 水とは異なっている. また, 出水規模が半分程度である ことも重なり，底質浮遊フラックスは北向きに輸送され たものと考えられる。これらの結果より, 出水のピーク が上げ潮付近，または下げ潮付近のどちらの潮位に重な るかによって, 河口付近での底質浮遊輸送フラックスの 卓越移動方向が変化することが示され, 河川流量と潮位 の位相差が土砂移動に与える影響の重要性が現地観測に より確認された。

\section{5. 結論}

潮間帯干潟において, 地盤高と底質浮遊フラックスの 現地観測結果を用いて潮汐運動の空間分布による土砂動 態への影響，および潮汐と河川出水の相対的な重要度の 検討を行った。本研究で得られた主要な結論は以下の通 りである.

（1）平常時の底質浮遊フラックスの時間変化は岸沖・沿
岸方向とも R2上の3 点は同じ傾向を示すが， R1上の D 点は位相が逆転し, 沿岸方向では北向きが卓越してお り，土砂収支の結果と一致する。

（2）式（2）の右辺第2項は無視できない大きさであり, 流速の空間分布は有意である.HFレーダの観測結果よ り湾全体の潮汐流が対象海域付近で南向きの反流を生 じていることが確認された.

（3）土砂収支検討期間外の期間では，出水時 R1 境界で北 向きの土砂流入が生じている時期が確認された。そこ で, 河川流量と潮位の時系列を比較したところ, 出水 のピークが干潮，あるいは，満潮付近と重なるかによ って土砂移動の方向が変化し, 両者の位相差の重要性 が現地データで確認された。

今後は，観測結果を説明できる数值モデルの構築を行 い，地球温暖化に伴う潮間帯域のリスク評価と対策の一 助としたい.

謝辞：本研究は文部科学省科学研究費による研究の一部 であることを付記し，謝意を表します。

\section{参 考 文 献}

栗山善昭・橋本孝治（2004）：熊本県白川河口干潟における土 砂収支，港湾空港技術研究所資料，No.1074，16p.

西 敬浩 - 郷原慎一郎・Charles Lemckert - 外村隆臣・山本浩 一・濱田孝治・山田文彦（2010）：ラグランジュ・ブイを 用いた潮間帯での渦動粘性係数・渦拡散係数の時空間分 布推定, 土木学会論文集 B2（海岸工学）, B2-66（投稿中） 山田文彦・坂西由弘・山口龍太・蒲原さやか - 穴井広和 - 小 林信久·玉置昭夫・多田彰秀 (2007) : 潮汐位相平均を用 いた潮間帯上の底質輸送フラックスの時空間変動特性, 海岸工学論文集，第 54 巻, pp. 626-630.

山田文彦 · 白川雄一郎 - 穴井広和 - 草合由友 ·坂西由弘 - 山 本浩一・小林信久（2009）：シルト・粘土の質量に基づく 土砂収支法の提案と河口潮間帯干潟への適用，土木学会 論文集 B2 (海岸工学), B2-65, pp. 476-480.

Friedrichs, C. T., and Aubrey, D. G. (1996) : Uniform bottom shear stress and equilibrium hypsometry of intertidal flats, Mixing in estuaries and coastal seas, C. Pattiaratchi, ed., Am. Geophys. Union, Washington D.C., pp. 405-429.

Harris, K. C., Traykovski, P., and Geyer, W. R. (2005) : Flood dispersal and deposition by near-bed gravitational sediment flows and oceanographic transport: A numerical modeling study of the Eel River shelf, north California, Journal of Geophysical Research, 110, C09025, doi:10.1029/2004JC002727

Le Hir, P., W. Roberts, O. Cazaillet, M. Christie, P. Bassoullet and C. Bacher (2000): Characterization of intertidal flat hydrodynamics, Continental Shelf Research, 20, pp. 14331459 .

Yamada F., Kobayashi, N., Sakanishi, Y. and Tamaki, A. (2009): Phase averaged suspended sediment fluxes on intertidal mudflat adjacent to river mouth, Journal of Coastal Research, 25 , pp. $350-358$. 